\author{
Mevlida Operta \\ University of Sarajevo, Sarajevo-Bosnia and Herzegovina \\ mevlidaoperta@gmail.com
}

\begin{tabular}{l|l|l}
\hline DOI & http: //dx.doi.org/10.12739/NWSA.2018.13.2.4A0057 \\
\hline \multicolumn{2}{l}{ ORCID ID } & $0000-0002-3028-2294$ \\
\hline
\end{tabular}

\title{
FRACTURE (VEIN) MINERALS IN AMPHIBOLITE ROCKS ON THE SOUTHERN EDGE OF THE KRIVAJA-KONJUH MASSIF (BOSNIA AND HERZEGOVINA) \\ ABSTRACT
}

One of the impressive geological formations in Bosnia and Herzegovina is part of the Dinarides Central Ophiolite Zone, known in literature as the Bosnian Ophiolite Zone. Within the ophiolite zone, there are 6 ophiolite complexes in Bosnia among which the KrivajaKonjuh Ophiolite Complex stands out with its size. The paper presents the results on research to date of fracture (vein) minerals in the Bosnian Ophiolite Zone, with accent put on research of vein (fracture) minerals on the southern edge of the Krivaja-Konjuh Ophiolite Complex. The following were conducted in the research on fracture (vein) minerals: an optical examinations by polarization microscope, $x-r a y$ examinations and chemical analysis by an electronic microprobe. The following were determined as fracture (vein) minerals in amphibolite rocks: prehnite, zeolite minerals (laumontite, thomsonite, mesolite and analcime), epidote-clinozoisite, chlorite, calcite, then plagioclases, quartz, garnet minerals and corundum. In contact zone between these rocks and metadiabases, the followings were determined: prehnite, epidote and subordinate clinozoisite and quartz.

Keywords: Results, Research, Fracture (vein) Minerals, Central Ophiolite Zone, Krivaja-Konjuh Massif

\section{ŽILNI (PUKOTINSKI) MINERALI U AMFIBOLITSKIM STIJENAMA JUŽNOG OBODA KRIVAJSKO-KONJUŠKOG MASIVA (BOSNA I HERCEGOVINA)}

\begin{abstract}
Jedna od markantnih geoloških formacija Bosne i Hercegovine je dio Centralne ofiolitske zone Dinarida, poznata u literaturi kao Bosanska ofiolitska zona. U okviru ofiolitne zone u Bosni postoji 6 ofiolitnih kompleksa među kojima se veličinom ističe Krivajskokonjuški ofiolitski kompleks. U radu su prikazani rezultati dosadašnjih istraživanja žičnih (pukotinskih) minerala u Bosanskoj ofiolitskoj zoni, s tim da je akcenat dat na istraživanje žilnih minerala na južnom obodu krivajsko-konjuškog ofiolitskog kompleksa. Pri istraživanju pukotinskih minerala izvršena su: optička ispitivanja polarizacionim mikroskopom, rentgenska ispitivanja i hemijske analize elektronskom mikrosondom. Kao pukotinski minerali u amfibolitskim stijenama utvrđeni su: prenit, zeolitski minerali (lomontit, tomsonit, mezolit i analcim), epidot-klinocoizit, hlorit, kalcit, te plagioklasi, kvarc, granatski minerali i korund. U kontaktnoj zoni ovih stijena sa metadijabazima određeni su: prenit, epidot i podređeno klinocoizit i kvarc.

Ključne Riječi: Reultati, Istraživanja, Žilni (Pukotinski) Minerali, Centračna Ofiolitska Zona, Krivaja-Konjuh Massif
\end{abstract}

How to Cite:

Operta, M., (2018). Fracture (Vein) Minerals in Amphibolite Rocks on The Southern Edge of The Krivaja-Konjuh Massif (Bosnia And Herzegovina), Nature Sciences (NWSANS), $13(2): 18-31$, DOI: 10.12739/NWSA.2018.13.2.4A0057. 


\section{INTRODUCTION}

Ophiolite zone of Internal Dinarides is a separate tectonic unit and it stretches from Banija in Croatia through Bosnia and western Serbia, to Kosovo on southeast and continues to Hellenides. Within ophiolite zones in Bosnia, there are 6 ophiolite complexes (KrivajaKonjuh, Ozren, Kozara, Varde and Višegrad area, complex Ljubić, Čavke and Vrbanje, and complex Borje and Mahnjače) mainly identical composition, although each carries some specific characteristics that makes it different from other complexes. Krivaja-Konjuh complex is located in the central parts of the ophiolite zone of the Dinarides and is elongated in the northwest-southeast direction. The dominant role in Krivaja-Konjuh massif have ultramafic rocks occupying an area of over $500 \mathrm{~km}^{2}$ and they are associated with different varieties of igneous rocks and metamorphic rocks. Fracture (vein) minerals from rocks in Bosnia and Herzegovina's Ophiolite Zone, for many years have been examination subject of secondary interest, so the data on them are stated only within petrologic investigation results. In one of his first papers [1] (Baumgartel, 1904) based on the research results on the chromite deposit's surrounding rocks in Duboštica, data on research of "secondary formations" were published and chromite coating, tremolite and plagioclase veins were determined. Certain attention was payed to occurrence of vein facies and products of postigneous crystallization stage in Višegrad area [2] (Trubelja, 1957) during petrologic research on igneous rocks in the vicinity of Višegrad. On the base of detailed optical research and chemical analysis, hornblende, clinozoisite, prehnite, chlorite and quartz with pyrite and chrysotile were determined.

More intensive fracture (vein) minerals research in Bosnian igneous rocks was conducted in period 1970-1980. In that period, xonotlite was determined from the Mountain of Borja [3] (Džepina, 1970) and from the vicinity of Višegrad [4] (Trubelja, 1971, 1972/73), then scolecite and stilbite, also from the area of Višegrad [] (Šibenik-Studen, 1972/73, 1974) and thomsonite from eastern slopes of the Konjuh Mountain (Šibenik, Studen and Trubelja, 1971). Studying Dinaride ophiolites as indicators of $\mathrm{P}-\mathrm{T}$ conditions as well as vein mineral paragenesis, stated are: prehnite, epidote, chlorite, calcite, albite, amphibole, xonotlite and pectolite. Comparing this vein mineral paragenesis with literature data [] (Myashiro et Shido, 1970 and Winkler, 1970), Pamić concludes that post-consolidation changes in igneous-sediment Jurassic formation in Dinarides Ophiolite Zone were conducted in $\mathrm{P}-\mathrm{T}$ conditions which dominated in interval between zeolite and greenschist facies.

By analyzing the Krivaja-Konjuh Complex as unique geologic unity, in the frame of which Pamić et al., (1977) consider also metamorphic stage of Jurassic igneous-sediment formation, as the most often vein minerals, they stated the following: prehnite, epidote, clinozoisite and calcite, and less frequently chlorite, quartz and albite. Analcime, laumontite, natrolite and datolite from the vicinity of Banja Luka were explored by Đorđević and Stojanović (1974). During the years of 1976 and 1977, Šibenik and his associates explored fracture minerals from the wider area of Višegrad. Đorđević (1978) also explored mentioned area and he found fracture minerals of pectolite and grossular. As the central part of the Ophiolite Zone in Bosnia and Herzegovina has been poorly explored, Šibenik and Sijarić with their associates $(1977,1978,1989)$ conducted their research and determined occurrences of the following: laumontites, thomsonites, clinozoisites and actinolites in amphibolite rocks in the Vijaka's area. 
Studying of vein minerals in amphibolite rocks on the southern edge of the Krivaja-Konjuh massif, Pamić and his associates (1979) came to an identical results for diabase-dolerite. In fact, they often contain minerals: prehnite, epidote-clinozoisite and tremolite, and thomsonite and laumontite of zeolites, although very rarely. The aim of this paper is to present a review on fracture (vein) minerals and to present results on detailed laboratory analysis of these minerals for amphibolite rocks on the southern edge of the Krivaja-Konjuh massif (in the area of Vijaka village, near Vareš), analyzed in detail by surface and subsurface exploration. For the majority of vain minerals, a tabular overview of their chemical composition was given and mode of their occurrences and genesis was examined.

\section{RESEARCH SIGNIFICANCE}

I have worked on the researches for the purpose of developing a PhD thesis aimed at determining the mineral and chemical composition of metamorphic rock-amphibolite and amphibolite shrubs that were previously only explored in the period 1969-1978. These more detailed laboratory examinations also identified some cracking minerals that were not previously discovered. They have not been subjected to any detailed laboratory examination. Investigations include minerals and rock samples and from the depths of exploration wells. All obtained results were used to determine the thickness of the crust decomposition, reserves and determination of the possibility of using these rocks.

\section{GEOLOGICAL CHARACTERISTICS OF THE DINARIDE OPHIOLITE ZONE}

Ophiolite complex rocks are related to the internal Dinarides and they represent very complex association of rocks among which ultramafites are the most characteristic ones which are associated with different varieties of gabbros, dolerite, diabases, spilite and amphibolites and united in the so-called diabase-chert formation or Jurassic-igneous-sedimentary formation (Katzer, 1906.; Ćirić, 1954.; Pamić, 1964.). Various types of gabbros, dolerites, diabases and spilites constitute about 5-10\% ophiolite complex (Pamić, 1964). Ophiolite zone of the Dinarides has been camouflaged in some parts, with drawn Mesozoic, mainly calcareous and Paleozoic semimetamorphic rocks. In ophiolite complexes of the Dinarides ophiolite zones, prevail ultramafites (lherzolites, harzburgites) and serpentinite. Very rarely one encounters complete preserved ophiolite profiles (Pamić\&Desmons, 1989), but more often the chaotic relationships, i.e. ophiolite mélange (Dimitrijević, 1973) is present. Ophiolite mélange is built of shale-silt matrix in which they are usually fragments of greywackes, radiolarites and exotic limestones of Middle Triassic to Jurassic-Lower-Cretaceous age. In the mélange, there are also fragments and blocks of ophiolites centimeter-decimeter-hectometer-the kilometer in size. As the most dominant rocks in the ophiolite mélange appear fragments and blocks of peridotites represented by faulted plates, thickness from a few hundred meters to 2000 meters, drawn on ophiolite mélange (Pamić and Desmons, 1989).

So far, in the ophiolite mélange, means in its matrix, typical fossil remains have not been found. Based on uncharacteristic fossils, Jurassic age is assumed, which is consistent with available data on isotopic age 189-136 Ma (Lanphere et al., 1975; Mayer et al., 1979; Lugović et al., 1991). Over the ophiolite mélange of the Dinarides ophiolite zone lie transgressive Lower cretaceous formations of Pogarska formation. 


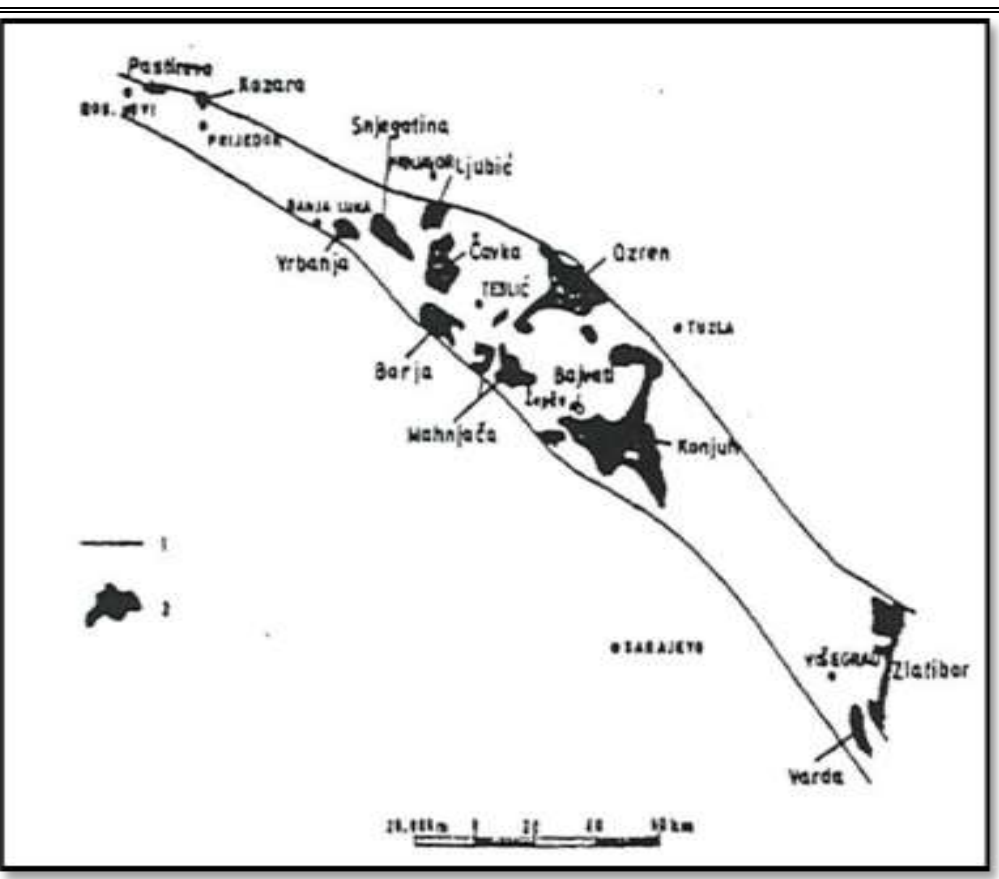

Figure 1. Schematic map of northwestern and middle parts of the Dinaride Ophiolite zone (Pamić et al., 1977). 1. boundary of the Ophiolite zone. 2. larger ultramafic massifs

\subsection{Krivaja-Konjuh Ophiolite Complex}

About Krivaja-Konjuh ophiolite complex, there is a large number of works related to certain small areas (Pamić, et al., 1977., Pamić, 1978:, Operta et al., 2003., Trubelja et al., 1995., Šegvin, B., 2010., Faul et al., 2014). Krivaja-Konjuh complex extends from the Bosna river valley in the west to the road Sarajevo-Tuzla in the east. In the north, i.e., the northwest, boundary is not visible, while to the south it extends to Vareš. Through the central part of the ophiolite complex the river Krivaja flows dividing it into two equally sized blocks, after which and after the neighboring mountain Konjuh the complex got its name. The dominant role in the Krivaja-Konjuh massif have ultramafite rocks occupying an area of over $500 \mathrm{~km}^{2}$ and they are associated with different varieties of igneous rocks and metamorphic rocks (amphibolites, amphibolite schists and eclogites). Amphibolites form narrower or wider zones around ultramafite massif and in some areas they exceed ultramafic in size. All these rocks are members of the Jurassic ophiolite mélange with a dominant share of greywacke sandstones and slates. Krivaja-Konjuh ophiolite complex together with ophiolite mélange covers an area of approximately $1000 \mathrm{~km}^{2}$ (Pamić, 1978). Over the ophiolite mélange, synclinally lies Pogari Formation of Tithonian-Cretaceous age and over the KrivajaKonjuh ultramafic massif in the area sokoline, transgressivelly lie the Upper Jurassic limestones. This suggests that age of ophiolite mèlange falls between the Jurassic and Tithonian. Phyllite and quartzsericite schists were spotted in the central part of the southern perimeter of Duboštica and on the east end at Konjuh to Miljevice, similar in appearance to match the Paleozoic formations. It is supposed they represent the transformed greywacke sandstones and slates of Jurassic ophiolite mèlange. 


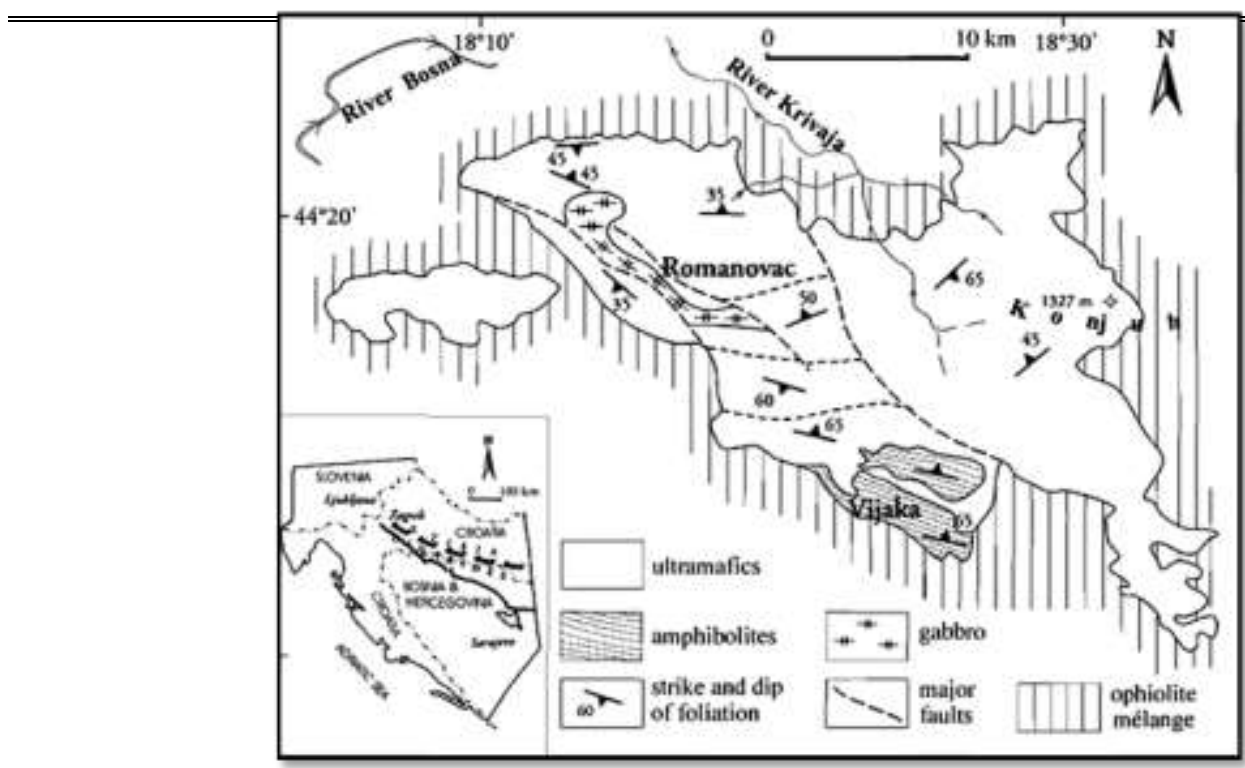

Figure 2. Schematic structural map of Krivaja-Konjuh massif (Pamić et al., 1977)

Ophiolite complexes of various geographical areas mainly have identical composition. Mafic rocks are much subordinated; they occur frequently but in smaller masses. The relationship between ultramafic and mafitc, including amphibolites, is 9 to 1 (Pamić, 1978). Rarely one can encounter a fully preserved ophiolite profiles. Usually the complete ophiolite profiles in ophiolite situating are broken, tectonised, and, as smaller or larger fragments, they are included in ophiolite mélange.

\section{RESEARCH METHODS}

Sampling of fracture (vein) minerals was conducted on amphibolite rock samples from floors-incision and from investigation boreholes on six sites. Microscopic preparations of minerals and rocks were optically tested on standard Leitz microscope. For detailed laboratory investigations, 19 samples were chosen, later tested by the method of $x$-rays diffraction, and chemical composition was determined by electronic microprobe. Analyses were done at the Institute for Mineralogy and Petrography in Innsbruck (Austria).

\section{RESEARCH RESULTS AND DISCUSSION}

The researches on fracture minerals in amphibolite rocks on the southern edge of the Krivaja-Konjuh massif have so far been conducted on samples tested from surface zones. Samples taken from exploration boreholes from various depths were also included by the research. However, with previous research, minerals have not been tested with electronic microprobe. During the testing and detailed geological mapping of floors-incisions and research boreholes, it was microscopically noticed that fracture minerals occur in veins with the thickness of $2 \mathrm{~mm}$ to $3 \mathrm{~cm}$, and rare in the form of coatings or scums. These minerals have been established in weathering of amphibolite rocks crust and in deeper boring intervals (Figure 3, 4, 5 and 6). Zeolite minerals, not only being found as fracture minerals, very often they occur as coatings and scums in weathering of amphibolite rocks crust. Stated minerals are found in veinsthickness $2 \mathrm{~mm}$ to $3 \mathrm{~cm}$, and rare in the form of clusters. Zeolite minerals are often found in paragenesis with prehnite, clinozoisite, epidote and calcite. Of 
zeolite minerals, determined are: laumontite, thomsonite, mesolite and analcime. Laumontite is determined by x-ray analysis as a fracture mineral in altered diabases of the Ophiolite Zone in Bosnia, found in veins with thickness to $10 \mathrm{~mm}$ (Đordević, 1975). This is often fracture mineral in diabases in the area of Višegrad, while analcime, calcite and prehnite have less participation (Đordević and Stojanović, 1974; Đorđević, 1975; 1976). In amphibolite rocks on the southern edge of the Krivaja-Konjuh massif, laumontite is determined by detailed laboratory investigation (chemical analysis and $x$-ray examinations). The mineral is fine-crystalline, often powdery and friable (Figure 3).

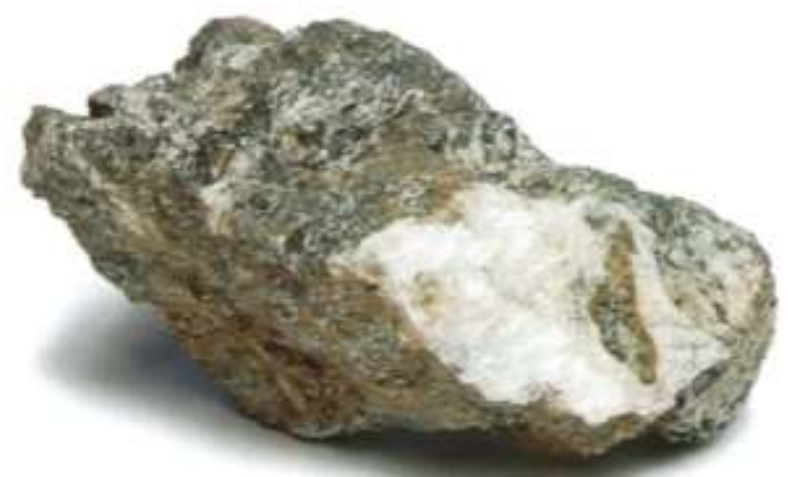

Figure 3. Laumontite in the form of coatings and veins in amphibolite rocks on the southern edge of the Krivaja-Konjuh massif

Thomsonite, analcime and mesolite also occur in above mentioned rocks. Thomsonite is often in association with titanite and ilmenite, while the content of analcime is much more subordinate in compare to the mentioned minerals.

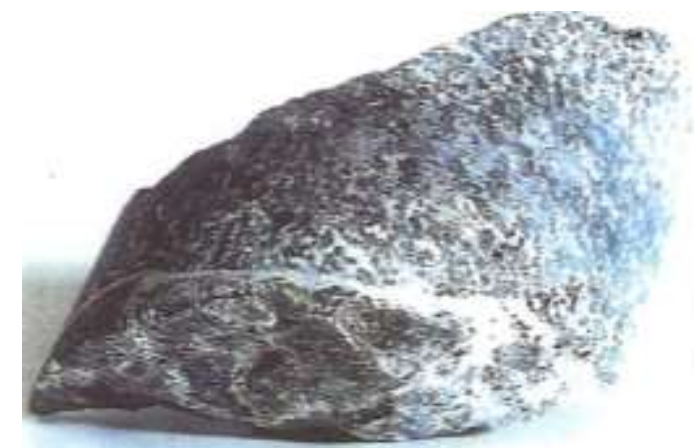

Figure 4. The amphibolite rock's core with laumontite coatings, sampled from investigation boreholes from the depth of $15 \mathrm{~m}$

Chemical analysis of thomsonites from amphibolite rocks of the Vijaka area near Vareš have been calculated on the base of 80 o (Table 1, analysis 5, 6 and 7), and mesolites on 30 o (Table 2, analysis 1). Chemical analysis of analcimes have been calculated on the base of 7 o. The results on chemical researches have been given in the table 2 (analysis 2). Prehnite occurrences have also been determined in other parts of the Ophiolite Zone in Bosnia, for example in wider area of Banja Luka (Bojići) and Višegrad (Bikavac). On the locality of Bojići, prehnite has been found in diabases, usually in association with natrolite and it fills cavities in rock mass, being a base to natrolite. Prehnite is determined by optical testing, as well as by $x-$ ray and thermal testing (Đorđević and Stojanović, 1972). Prehnite is also found in the locality of Bikavac, as a vein mineral. It is 
subordinately presented in thick veins originated by over-filling cracks in which laumontite dominates, along with analcime and calcite. However, in this site prehnite is determined microscopically, as well as by x-ray examinations and thermal testing (Đordević, 1976). In amphibolite rocks on the southern edge of the Krivaja-Konjuh massif, prehnite occurs in the form of coatings as well as fracture mineral. Prehnite determining was done by optical testing and microprobe chemical analysis. Beside that prehnite is found along with zeolite minerals, it is usually in association with calcite, epidote and clinozoisite.

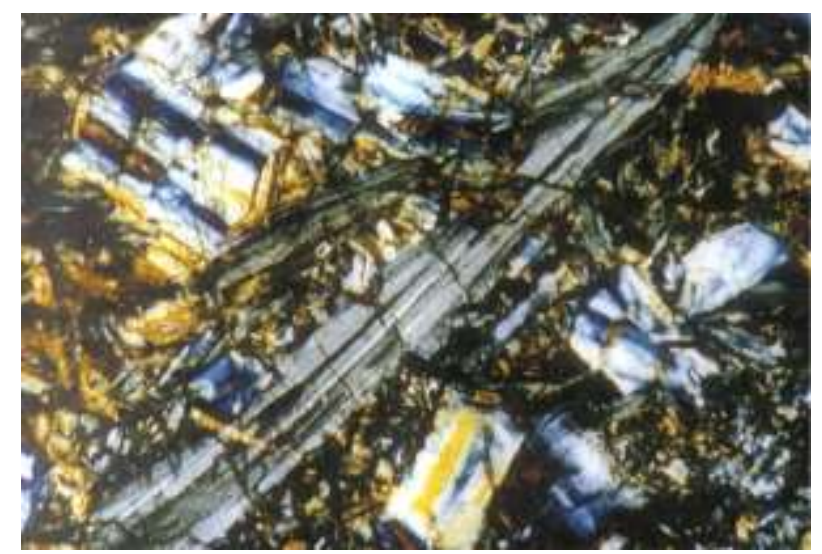

Figure 5. Midstream crystals of clinozoisite with grey interference colors and epidote crystals with interferencelively colors of the second and third class

Epidote occurs in veins, radially aggregates or in the form of greenish-colorcoatings, and calcite in powdery, soil aggregates and in crystals of rhombohedral habitus. Calcite as well as epidote occurrences, have been ascertained also in deeper boring intervals. Plagioclases, as important ingredients of these rocks, are rarely fresh and mostly they are altered into prehnite, that is, they are prehnitized. By optical testing and analysis on chemical composition, basic plagioclases (labrador-bitovnite) were determined. Prehnite chemical analysis have been calculated on the base of 24 (O, OH), and they are shown in the table 1 (analysis 1-4). Beside that prehnite is found along with zeolite minerals, it is usually in association with calcite, epidote and clinozoisite. Epidote occurs in veins, radially aggregates or in the form of greenish-colorcoatings, and calcite in powdery, soil aggregates and in crystals of rhombohedral habitus. Calcite as well as epidote occurrences, have been ascertained also in deeper boring intervals. 
Operta, $M$.

Nature Sciences (NWSANS), 4A0057, 2018; 13(2): 18-31.

Table 1. Selected chemical analysis on fracture (vein) minerals in amphibolite rocks on the southern edge of the Krivaja-Konjuh massif

\begin{tabular}{|c|c|c|c|c|c|c|c|}
\hline & 1 & 2 & 3 & 4 & 5 & 6 & 7 \\
\hline $\mathrm{SiO}_{2}$ & 43.55 & 42.97 & 42.54 & 43.13 & 41.97 & 42.72 & 37.43 \\
\hline $\mathrm{TiO}_{2}$ & 0.08 & 0.00 & 0.08 & 0.04 & & & 0.00 \\
\hline $\mathrm{Al}_{2} \mathrm{O}_{3}$ & 23.19 & 23.67 & 23.60 & 23.70 & 27.24 & 27.98 & 30.24 \\
\hline $\mathrm{Cr}_{2} \mathrm{O}_{3}$ & 0.02 & 0.00 & 0.12 & 0.12 & 0.21 & & 0.14 \\
\hline $\mathrm{Fe}_{2} \mathrm{O}_{3}$ & 0.84 & 1.00 & 1.29 & 1.09 & 0.27 & & 0.42 \\
\hline FeO & 0.26 & 0.31 & 0.40 & 0.34 & & & \\
\hline $\mathrm{MnO}$ & 0.11 & 0.13 & 0.04 & 0.00 & & & 0.06 \\
\hline $\mathrm{MgO}$ & 0.01 & 0.05 & 0.04 & 0.12 & & & \\
\hline $\mathrm{CaO}$ & 27.12 & 27.06 & 27.49 & 27.07 & 11.18 & 10.64 & 13.75 \\
\hline $\mathrm{Na}_{2} \mathrm{O}$ & 0.15 & 0.04 & 0.00 & 0.07 & 4.71 & 4.71 & 3.80 \\
\hline $\mathrm{K}_{2} \mathrm{O}$ & 0.10 & 0.06 & 0.18 & 0.00 & 0.03 & 0.00 & 0.00 \\
\hline $\mathrm{H}_{2} \mathrm{O}$ & 4.44 & 4.43 & 4.46 & 4.45 & 13.51 & 13.41 & 13.30 \\
\hline total & 99.87 & 99.67 & 100.24 & 100.13 & 99.12 & 99.46 & 99.24 \\
\hline Si & 6.021 & 5.952 & 5.885 & 5.946 & 22.431 & 22.756 & 20.347 \\
\hline Al & 1.979 & 1.924 & 2.115 & 2.054 & 17.174 & 17.423 & 19.437 \\
\hline Al & 1.797 & 1.820 & 1.732 & 1.796 & 0.000 & 0.000 & 0.000 \\
\hline $\mathrm{Cr}$ & 0.000 & 0.000 & 0.134 & 0.000 & 0.177 & 0.000 & 0.122 \\
\hline $\mathrm{Fe}+3$ & 0.087 & 0.104 & 0.008 & 0.113 & 0.108 & 0.000 & 0.049 \\
\hline $\mathrm{Fe}+2$ & 0.030 & 0.036 & 0.008 & 0.039 & 0.000 & 0.000 & 0.000 \\
\hline Mn & 0.013 & 0.015 & 0.046 & 0.000 & 0.000 & 0.000 & 0.028 \\
\hline $\mathrm{Mg}$ & 0.002 & 0.010 & 0.005 & 0.024 & 0.000 & 0.000 & 0.000 \\
\hline $\mathrm{Ti}$ & 0.008 & 0.000 & 0.000 & 0.004 & 0.000 & 0.000 & 0.000 \\
\hline $\mathrm{Ca}$ & 4.013 & 4.014 & 4.072 & 3.997 & 6.399 & 5.937 & 7.948 \\
\hline $\mathrm{Na}$ & 0.040 & 0.011 & 0.031 & 0.018 & 4.878 & 4.789 & 1.922 \\
\hline $\mathrm{K}$ & 0.008 & 0.011 & & & 0.020 & 0.000 & 0.000 \\
\hline $\mathrm{Zn}$ & & & & & 0.000 & 0.000 & 0.000 \\
\hline $\mathrm{Ni}$ & & & & 0.000 & 0.000 & 0.000 & 0.000 \\
\hline $\mathrm{OH}$ & 4.090 & 4.096 & 4,113 & 4.090 & 0.000 & 0.000 & 0.000 \\
\hline $\mathrm{H}_{2} \mathrm{O}$ & & & & & 24.090 & 23.910 & 23.710 \\
\hline
\end{tabular}

In the contact area between amphibolite rocks and serpentinite at one site, the larger amount of clinochlore, a layered aggregate which is found in the form of interlayers, were determined. clinochlore sporadically occurs on two other sites as well (Table 2, analysis 3). In corundum varieties of amphibolite rocks, tested from incision-floors, cracks have been noticed, filled with fresh basic plagioclase (anorthite) and prehnitized basic plagioclases. By x-ray examination and chemical analysis, veins filled with corundum have been determined in these rocks (Table 2, analysis 4). By x-ray examinations of the corundum composition, a presence of clinochlore inclusions in corundum and inclusions of tschermakite hornblende, plagioclases and margarite mica were determined. (Operta et al., 2003). 
Table 2. Selected chemical analysis of fracture (vein) minerals in amphibolite rocks on the southern edge of the Krivaja-Konjuh massif

\begin{tabular}{|c|c|c|c|c|}
\hline & 1 & 2 & 3 & 4 \\
\hline $\mathrm{SiO}_{2}$ & 42.94 & 53.94 & 32.74 & \\
\hline $\mathrm{TiO}_{2}$ & 0.16 & 23.79 & 0.34 & \\
\hline $\mathrm{Al}_{2} \mathrm{O}_{3}$ & 27.06 & 0.60 & 12.96 & 99.28 \\
\hline $\mathrm{Cr}_{2} \mathrm{O}_{3}$ & 0.00 & & 0.27 & 0.04 \\
\hline $\mathrm{Fe}_{2} \mathrm{O}_{3}$ & 0.79 & 0.60 & & \\
\hline FeO & 0.00 & 0.24 & 9.98 & 0.25 \\
\hline $\mathrm{MnO}$ & 0.09 & & 0.04 & 0.00 \\
\hline $\mathrm{MgO}$ & 0.14 & & 28.56 & 0.00 \\
\hline $\mathrm{CaO}$ & 9.88 & 0.12 & 0.61 & 0.00 \\
\hline $\mathrm{Na}_{2} \mathrm{O}$ & 4.68 & 11.09 & 0.07 & 0.00 \\
\hline $\mathrm{K}_{2} \mathrm{O}$ & 0.11 & 0.52 & 0.18 & 0.00 \\
\hline $\mathrm{NiO}$ & & & & 0.02 \\
\hline $\mathrm{H}_{2} \mathrm{O}$ & 13.54 & 8.71 & 13.67 & \\
\hline total & 99.39 & 99.01 & 99.42 & 99.68 \\
\hline $\mathrm{Si}$ & 8.569 & 1.985 & 6.784 & \\
\hline Al & 6.361 & 1.031 & 1.513 & \\
\hline Al & 0.000 & & 1.532 & \\
\hline $\mathrm{Cr}$ & 0.000 & & 0.085 & \\
\hline $\mathrm{Fe}+3$ & 0.118 & 0.166 & & \\
\hline $\mathrm{Fe}+2$ & 0.000 & 0.007 & 1.646 & \\
\hline $\mathrm{Mn}$ & 0.015 & & 0.007 & \\
\hline $\mathrm{Mg}$ & 0.042 & & 8.411 & \\
\hline $\mathrm{Ti}$ & & & 0.051 & \\
\hline $\mathrm{Ca}$ & 0.024 & 0.005 & 0.027 & \\
\hline $\mathrm{Na}$ & 2.112 & 0.791 & 0.046 & \\
\hline K & 1.810 & 0.024 & & \\
\hline $\mathrm{Zn}$ & 0.000 & & & \\
\hline $\mathrm{Ni}$ & 0.000 & & & \\
\hline $\mathrm{OH}$ & 0.000 & 2.083 & 16.000 & \\
\hline $\mathrm{H}_{2} \mathrm{O}$ & 24.090 & & & \\
\hline
\end{tabular}

By investigation boring, it was also ascertained that garnet varieties of amphibolite rocks contain much of sulphide minerals (pyrites and arsenopyrites) and that they are cut by cracks filled with slated serpentinites (Operta et al., 2011). Minerals of the garnet group in the form of veins can be found rarely (table 3). The presence of veins filled with albite in rocks is confirmed by $x-r a y$ examinations and microprobe analysis. Besides albite, subordinate thomsonite participation was also determined. The chemical composition of garnets in garnet varieties in metamorphic rocks from the southern edge of the Krivaja-Konjuh massif is determined by electronic microprobe. By shooting the garnet's grain by dot method using electronic microprobe, it has been noticed that garnets show large variations in chemical composition. By dividing garnet's composition on end members, it is evident that all garnets represent almost nonstop series, where changes in proportions of almandine and pyrope are especially interesting. Variations of end members are: pyrope (3450\%); almandine (31-51\%); grossular (3-17\%); andradite (4-12\%); spessartine $(1-5 \%)$ and uvarovite $(0.0-0.7 \%)$. 
Table 3. Selected chemical analysis of garnets in amphibolite rocks, weight : and formula calculation on the base of 120 , at components $\operatorname{mol}$. $\%$

\begin{tabular}{|c|c|c|c|c|c|}
\hline Samples & 1 & 2 & 3 & 4 & 5 \\
\hline $\mathrm{SiO}_{2}$ & 38.56 & 37.86 & 38.91 & 38.62 & 37.55 \\
\hline $\mathrm{TiO}_{2}$ & 0.00 & 0.00 & 0.00 & 0.00 & 0.15 \\
\hline $\mathrm{Al}_{2} \mathrm{O}_{3}$ & 22.04 & 21.82 & 22.09 & 21.35 & 20.99 \\
\hline $\mathrm{Cr}_{2} \mathrm{O}_{3}$ & 0.09 & 0.00 & 0.05 & 0.00 & 0.10 \\
\hline $\mathrm{Fe}_{2} \mathrm{O}_{3}$ & 2.04 & 2.40 & 2.46 & 2.92 & 0.47 \\
\hline $\mathrm{FeO}$ & 21.70 & 23.06 & 17.68 & 20.74 & 28.46 \\
\hline $\mathrm{MnO}$ & 1.19 & 2.15 & 0.90 & 0.61 & 1.40 \\
\hline $\mathrm{MgO}$ & 9.62 & 8.65 & 9.56 & 8.93 & 3.54 \\
\hline $\mathrm{CaO}$ & 4.44 & 3.27 & 8.12 & 6.64 & 6.87 \\
\hline $\mathrm{Na}_{2} \mathrm{O}$ & 0.08 & 0.06 & 0.10 & 0.00 & 0.05 \\
\hline $\mathrm{K}_{2} \mathrm{O}$ & 0.00 & 0.05 & 0.01 & 0.11 & 0.00 \\
\hline Total & 99.75 & 99.32 & 99.88 & 99.91 & 99.58 \\
\hline Uvarovite & 0.300 & 0.000 & 0.200 & 0.000 & 0.300 \\
\hline Andradite & 6.000 & 7.200 & 7.200 & 8.600 & 1.400 \\
\hline Grosulare & 6.100 & 2.100 & 15.200 & 10.000 & 17.300 \\
\hline Pirope & 37.500 & 34.400 & 37.000 & 34.900 & 14.100 \\
\hline Spesartine & 2.600 & 4.900 & 2.000 & 1.300 & 3.200 \\
\hline Almandine & 47.400 & 51.400 & 38.400 & 45.200 & 62.800 \\
\hline Na-Ti grt & & & & & 0.800 \\
\hline Ti-Al grt & & & & & 0.100 \\
\hline Si & 2.951 & 2.939 & 2.949 & 2.958 & 2.997 \\
\hline Ti & 0.000 & 0.000 & 0.000 & 0.000 & 0.009 \\
\hline Al & 1.988 & 1.996 & 1.974 & 1.927 & 1.961 \\
\hline $\mathrm{Cr}$ & 0.005 & 0.000 & 0.003 & 0.000 & 0.006 \\
\hline $\mathrm{Fe}^{3+}$ & 0.117 & 0.140 & 0.14 & 0.168 & 0.028 \\
\hline $\mathrm{Fe}^{2+}$ & 1.389 & 1.496 & 1.080 & 1.019 & 0.095 \\
\hline Mn & 0.077 & 0.141 & 0.659 & 0.545 & 0.589 \\
\hline Mg & 1.097 & 1.000 & 0.059 & 0.040 & 0.095 \\
\hline $\mathrm{Ca}$ & 0.364 & 0.272 & 1.121 & 1.328 & 1.884 \\
\hline $\mathrm{Na}$ & 0.012 & 0.009 & 0.014 & 0.000 & 0.008 \\
\hline $\mathrm{K}$ & 0.000 & 0.000 & 0.001 & 0.011 & 0.000 \\
\hline Total & 8.000 & 7.993 & 7.999 & 7.996 & 7.999 \\
\hline
\end{tabular}

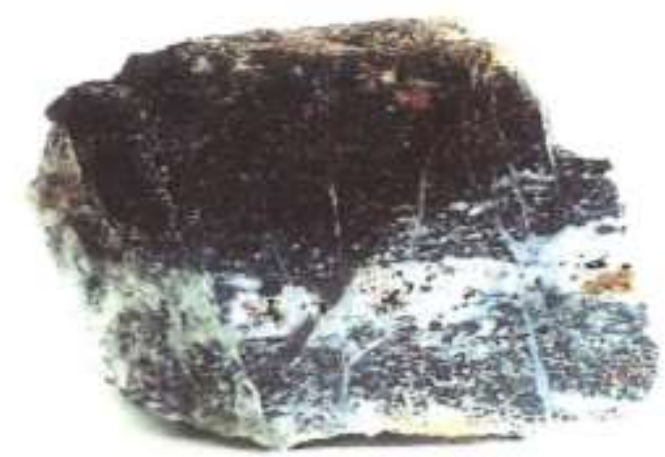

Figure 6. Garnet varieties of amphibolite rocks cut by veins which are filled with clinozoisite and prehnite

In contact zones of garnet varieties of amphibolite rocks with serpentinites on samples tested from incisions, it was noticed that the surface of the rocks was covered with zeolite minerals and that they are cut by veins filled with prehnite and pinky clinozoisite. 
In metadiabases, in contact with amphibolite rocks, veins filled with prehnite, epidote, and subordinated clinozoisite and quartz, thickness up to $20 \mathrm{~cm}$ (Figure 7.) were noticed. These samples have been optically tested on polarization microprobe, but they have not been analyzed by an electronic microprobe.

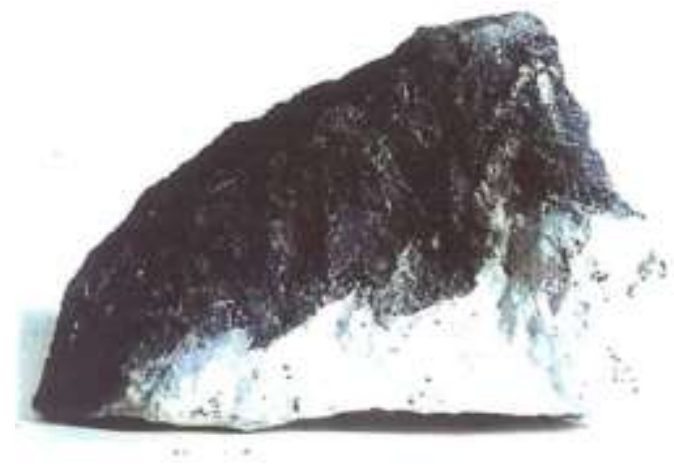

Figure 7. Metadiabases cut with cracks which are filled with prehnite, epidote, and subordinate clinozoisite and quartz

\section{CONCLUSION}

In amphibolite rocks on the southern edge of the Krivaja-Konjuh massif, prehnite, zeolite minerals, epidote-clinozoisite and less often calcite, quartz, plagioclases, garnet minerals and corundum gather into monomineral or polymineral veins (thickness from some $\mathrm{mm}$ to some $\mathrm{cm}$ ), or they make coatings or scums (nests). By this research, it was determined that minerals from zeolite group are found in paragenesis with prehnite, clinozoisite, epidote and calcite. However, it was proved that zeolites are not connected only to cracks in diabases, dolerites, spilites and gabbro rocks, but also to cracks of amphibolite rocks, and that they are also found on greater depths. Of zeolite minerals, beside already determined occurrences of laumontite and thomsonite, occurrences of mesolite and analcime were also determined. During testing and detail geological mapping of investigation works, calcite was also noticed as a fracture mineral in powdery, soil aggregates and crystals of rhombohedral habitus. It was testified by this that silicate rocks offer favorable physicalchemical conditions for grow of calcite in crystal forms, and that proves that mineral solutions with calcium material have flown through those rocks. By studying garnet varieties of amphibolite rocks with microprobe analysis, it was proved that veins were filled with mesolite (as alteration product), analcime and albite.

When it comes to genesis of zeolite group of minerals and minerals they are in paragenesis with, then the most authors consider that they are of hydrothermal origin and that they originated in late stage of post-igneous hydrothermal mineralization at a relatively low temperatures. In further consideration of genesis on these minerals, a possibility of their genesis through direct hydrothermal crystallization was accepted, or through crystallization from water solutions which increased the content of calcium, sodium, aluminum, and silicium mostly on account of change of plagioclase mineral from igneous rocks through which cracks circulation was done. In case of these minerals' occurrence in Ophiolite Zone in Bosnia, a direct hydrothermal crystallization in late post-igneous cycles is primary for their origin. Taking into account the stage of change, in first, minerals from plagioclase group in ophiolite rocks, for which was stated that prehnitization is of various intensity, the most often 
process of their change is enrichment of circulated solutions, in first ions of calcium, sodium, aluminum, silicium, through change of plagioclases of smaller dimensions. In this case, it could come interspersed to occurrence of pseudomorphosis of zeolites over plagioclases. It was also stated that, garnet varieties of amphibolite rocks contain enough sulphide minerals (pyrite and arsenopyrite) and that it is, probably, a fault zone along which splitting of rocks was performed and bringing of solutions from which sulphide minerals had been alkalized. In those varieties of metamorphic rocks, garnet rare occur as vein minerals.

\section{ACKNOWLEDGMENTS}

We are indebted to R. Tessadri and P. Tropper from the Institute of Mineralogy and Petrography, University of Innsbruck for his help during the laboratory work and to G. Tarmann for the financial support of this work.

\section{NOTICE}

This study was presented as an oral presentation at the I. International Scientific and Vocational Studies Congress (BILMES 2017) in Nevşehir/Ürgüp between 5-8 October 2017.

\section{REFERENCES}

[1] Barić, L.J., (1969). Korund aus der Umgebung des Dorfes Vijaka in Zentral Bosnien. Min, petr. Mus. Univ., Mitteil. 2., Zagreb.

[2] Baumgartel, B., (1904). Das Nebengestein der Chromeisenerzlagers-tatten bei Dubostica in Bosnien und das Auftreten von sekundargebildetem Chromit in demselben. Tschermarks Min. u Petr. Mitt. 23.

[3] Džepina, D., (1970). Rezultati mineraloško-petroloških ispitivanja regionalno metamorfisanih bazičnih stijena južnog dijela planine Borje u Bosni. Glasnik Prirodnjačkog muzeja u Beogradu, knj. 25, Ser. A, 129-144, Beograd.

[4] Đorđević, P., (1958). Bazični Eruptivi Okoline Vareša (Bosna). Zbornik radova Rudarsko-geoloskog fakulteta, sv. 5, (za 1957), 39-44, Beograd.

[5] Đorđević, P. and Mojičević, M., (1972). Albitski Sijenit sa Oboda Ultrabazitnog Masiva Planine Borje. Geološki Glasnik, 16, 137-143, Sarajevo.

[6] Đorđević, P. and Stojanović D., (1974). Analcim, Lomontit, Natrolit i Borni Mineral Datolit iz Dijabaznih Stijena Područja Banja Luka (Bosna, Jugoslavija). Glasnik Prirodnjačkog muzeja u Beogradu, knj. 29, Ser. A, 17-24, Beograd.

[7] Katzer, F., (1906). Istorijsko Razvijanje i Današnje Stanje Geoloških Proučavanja Bosne i Hercegovine, Glas. Zem. Muzeja B i $\mathrm{H} 18,37-68 . \check{z}$

[8] Katzer, F., (1911). Gabbrogesteine in Bosnien. Tschermak's min.petr. Mitt., 29(5), 453-468.

[9] Katzer, F., (1919). Das Serpentin und Gabrro-Vorkommen von Kostajnica bei Doboj in Bosnien.-Glas. Hrv. Prir. Društva, 31 , 96-97, Zagreb.

[10] Katzer, F., (1920). Minerali Bosne i Hercegovine. Klasa elemenata. Glasn. Zemaljskog muzeja u Bosni i Hercegovini. XXXII. str. 227-244.

[11] Kišpatić, M., (1897). Kristalinsko Kamenje Serpentinske Zone u Bosni. Rad Jugosl. Akad. znan Umj., 133, 95-231. 
[12] Kišpatić, M., (1900). Die krystallinischen Gesteine der bosnischen Serpentinzone.-Wissenschaft. Mitt. Aus Bosnien und Herzegovina, VII, 377-484, Wien.

[13] Operta, M., Pamić, J., Balen, D., and Tropper, P., (2003). Corundum-Bearing Amphibolites from The Metamorphic Basement of the Krivaja-Konjuh Ultramafic Massif (Dinaride Ophiolite zone, Bosnia). Mineralogy and Petrology, Springer-Verlang. 77, 287295.

[14] Operta, M.,(2003). Korundi u amfibolitima krivajsko-konjuškog ultramafitskog masiva kod Vareša, Geološki glasnik br. 35., str. 261-276, Građevinski fakultet Univerziteta u Sarajevu, Institut za geologiju, Sarajevo.

[15] Operta, M., Hyseni, S., Balen, D., Salihovic, S., and Durmishaj, B., (2011). Garnet Group Minerals from the Amphibolite Facies Metamorphic Rocks of Krivaja-Konjuh Ultramafic Massif in Bosnia and Herzegovina. ARPN Journal of Engineering and Applied Sciences (JEAS), Vol. 6. ISSN 1819-6608.

[16] Pamić, J. and Trubelja, F., (1962). Osnovne Geološko-Petrološke Karakteristike Ozren u Sjeveroistočnoj Bosni. Savez geol. Društva FNRJ, Ref. V. Savjet 2, 117-123, Beograd.

[17] Pamić, J., (1964). Magmatske i Tektonske Strukture u Ultramafitima Bosanske Serpentinske Zone. Poseb. Izdanje Geol. glas., knj.2, 1-108, Sarajevo.

[18] Pamić, J. ,(1966). Magmatske Formacije Dinarida, Vardarske Zone i Južnih Dijelova Panonskog Bazena. Monografija, Nafta, Zagreb, $\mathrm{pp}: 225$.

[19] Pamić, J., (1969). Ultramafitsko-Amfibolitska Masa Skatavice u Ofiolitnoj Zoni Dinarida (Bosna). Glasnik Zemaljskog Muzeja B i $\mathrm{H}, 8,35-45$.

[20] Pamić, J., (1970). Osnovne Petrološke Karakteristike Kromitskog Podrucja Doboštice u Bosni. Geol. glas. 14:135-148.

[21] Pamić, J. and Kapeler, I., (1971). Korundski Amfiboliti na Južnom Obodu Krivajsko-Konjuškog Ultramafitskog Masiva. Geol. anal. Balk. Poluostr., 35, 399-408.

[22] Pamić, J., Šćavničar, S., and Medjimorec, S., (1973). Mineral Assemblages of Amphibolites Associated with Alpine-Type Ultramafics in the Dinaride Associated with Alpine-Type Ultramafics in the Dinaride Ophiolite Zone (Yugoslavia), Journ. Petrology, Vol.14, pp:133-157.

[23] Pamić, J. and Majer, V., (1974). Eklogiti i Amfiboliti Crnog Potoka na južnom Obodu Ultramafitskog Masiva Planine Borje u Bosni. Geol. glas. 17, 119-133.

[24] Pamić, J., Sunarić-Pamić, O., Olujić, J., and Antić, R., (1977). Petrografija i Petrologija Krivajsko-konjuškog Ofiolitskog Kompleksa i Njegove Osnovne Geološke Karakteristike. Acta. Geol., 9, 39-135.

[25] Pamić, J., (1978). Krivajsko-konjuški kompleks. Geologija Bosne i Hercegovine, knj. IV, "Geonžinjering"-Sarajevo, 99-135.

[26] Pamić, J., Šibenik-Studen, M., and Sijarić, G., (1979). Postkonsolidacione Promjene na Bazičnim Stijenama iz Ofiolitske zone u Bosni, Glasnik Zemaljskog muzeja N. S XVII, Prirodne nauke, 13-41, Sarajevo.

[27] Pamić, J., (1982). Some Geological Problems of Dinaridic Ophiolites and Their Associations. Earth Evol Sci 2:30-35.

[28] Pamić, J., (1983). Consideration on the Boundary between lherzolite and Harzburgite Subprovinces in the Dinarides and Northern Hellenides. Ofioliti, 8, 153-164. 
[29] Pamić, J. and Hrvatović, H., (2000). Basic Data on the Geology and Petrology of the Krivaja-Konjuh Ophiolite Complex, Pancardi 2000, Dubrovnik, 60-67.

[30] Pamić, J., Tomljenović, B., and Balen, D., (2001). Geodynamic and Petrogenetic Evolution of Alpine Ophiolites from Central and NW Dinarides: an overview, Lithos 65, pp:113-142.

[31] Sijarić, G. and Šibenik-Studen, M., (1989). The Mineralogical Characterics of the Serpentines from Bosnia. Glasnik Zemaljskog muzeja Bosne i Hercegovine, 28, pp:65-89, Sarajevo.

[32] Šibenik, M. and Sijarić, G., (1980/81). Pukotinski Minerali u Bazičnim Magmatskim Stijenama iz Ofiolitske zone u Bosni, GZMsv. Za Prirodne nauke, XIX-XX, Sarajevo.

[33] Trubelja, F., (1957). Novi Rezultati Dobiveni pri Istraživanju Magmatskih Stijena Okolice Višegrada u Istočnoj Bosni, II Kongres geologa Jugoslavije, 311-325, Sarajevo.

[34] Trubelja, F., (1961). Magmatske Stijene Jugoistočnog Dijela Planine Konjuh (Bosna), Geološki glasnik, 5, 241-262, Sarajevo.

[35] Trubelja, F., (1963). Nova Pojava Albitskih Efuziva na Ljubić Planini u Bosni. Geol. Glasnik. 8, 29-32.

[36] Trubelja, F. and Pamić, J., (1965). Petrološka Studija Planine Ozren, Acta Geologica 4, 256-314.

[37] Trubelja, F., Šibenik-Studen, M., and Sijarić, G., (1974). Pukotinski Minerali u Bazičnim Magmatskim Stijenama u Bosni i Hercegovini, 8, Jugoslovenski geološki Kongres, Bled.

[38] Trubelja, F., Šibenik-Studen, M., and Sijarić, G., (1975). Prehnite in the rocks of Bosnia and Herzegovina, Izvještaj Jugosl. Centra za kristalografiju, vol, 10, JAZU, Zagreb. 